\title{
PRESUMPTIONS AND ASSUMPTIONS IN THE CRIMINAL LAW: ANOTHER VIEW $\dagger$
}

\author{
George C. Christie* and A. Kenneth Pye**
}

In a recent article ${ }^{1}$ H.A. Ashford and D.M. Risinger presented a thought-provoking "theoretical overview" of the constitutional aspects of presumptions and assumptions in the criminal law. In seeking to evaluate how well one aspect of criminal procedure uses the concept of "rationality" to achieve "justice," their discussion raised many interesting and important questions concerning the nature and quality of the criminal process. Although much of their analysis is unquestionably correct, we believe that some of its most basic theoretical positions are clearly erroneous and would not lead to either a fairer or a more rational criminal procedure. This article, accordingly, will begin by analyzing Ashford and Risinger's argument in the light of the present state of the law and will then proceed to a discussion of the broader implications of the theoretical questions their arguments raise.

I.

Ashford and Risinger quite properly stress that, while considerations of comparative convenience may have been the moving factors that have led to the use of presumptions in the trial of an issue of fact, such considerations of convenience, no matter how compelling, are not a constitutionally sufficient basis for upholding the use of presumptions in the criminal law. ${ }^{2}$ In order to satisfy Ashford and Risinger's test of constitutional validity, the use of presumptions in the trial of issues of fact in criminal proceedings must meet at least two further conditions: first, a "rational connection" must exist between what are called the "basic facts" and the "fact

$\dagger$ A preliminary version of this article was presented at a conference held at the Center for the Study of Democratic Institutions, Santa Barbara, California, on March 30-31, 1970.

* Professor of Law, Duke University. A.B. 1955, J.D. 1957, Columbia University; Dip. Int.

Law 1962, Cambridge University; S.J.D. 1966, Harvard University.

** Chancellor and Professor of Law, Duke University. B.A. 1951, University of Buffalo; J.D. 1953, LL.M. 1955, Georgetown University.

1. Ashford \& Risinger, Presumptions, Assumptions, and Due Process in Criminal Cases: $A$ Theoretical Overview, 79 Y ALE L.J. 165 (1969) [hereinafter cited as Ashford \& Risinger].

2. Id. at 180 . 
presumed"; second, there must be a high probability that innocent defendants will be able successfully to challenge the existence of the presumed fact so as to defeat the applicability of the presumption. ${ }^{3}$ Under their theory, as the likelihood that innocent defendants may challenge the existence of the presumed fact sufficiently to defeat the applicability of the presumption increases, the degree of rational connection between the basic facts and the presumed fact necessary to sustain the use of the presumption decreases. $\ln$ an example which Ashford and Risinger give, presumably as the limiting case, a rational connection or correlation between the existence of the basic facts and the presumed fact of 51 percent might be constitutionally sufficient if the probability that an innocent defendant will be able to defeat the applicability of the presumption is almost 100 percent. ${ }^{4}$ Thus their two-pronged test aims to assure that presumptions are used only when it is extremely unlikely that they will lead to the conviction of innocent defendants. In this regard, they completely reject the suggestion that the required strength of the logical connection between the basic facts and the presumed fact should vary according to the legislature's power validly to punish a man, if it so chose, merely on proof of the basic facts. ${ }^{5}$ As a subsidiary but important point, Ashford and Risinger insist that when the defendant comes forward with enough evidence to defeat the applicability of the presumption, the presumption should completely drop out of the picture. ${ }^{6}$ This is the socalled Thayer rule ${ }^{7}$ which has been adopted by the A.L.I.'s Model Penal Code. ${ }^{8}$ They reject the so-called A.L.I. minority view that, when the applicability of the presumption has been defeated, the judge may nevertheless instruct the jury that the basic facts may be regarded as "strong evidence" of the presumed fact."

Although the courts have not recognized the validity of some of the theoretical views advocated by Ashford and Risinger, the

3. Id. at $180-86$.

4. Id. at $185-86$.

5. Id. at $177-79$.

6. Id. at 194-202. In examining the various contentions made by Ashford and Risinger concerning the use of presumptions in the criminal law, we shall assume, for purposes of discussion, that they are correct in asserting that the same evidence will bave a greater impact on the jury when labeled a "presumption" than when it is not so labeled. There is, bowever, little empirical evidence available on tbe question.

7. J. Thayer, A Preliminary Treatise on the Law of Evidence 336-37 (1898).

8. Ali Model Penal Code $\S 1.12(5)$ (Proposed Off. Draft 1962) (formerly Ali Model Penal Code § 1.13(5) (Tent. Draft No.4, 1955)).

9. See Ali Model Penal Code $\S 1.13$, Alternative 5(c) (Tent. Draft No.4, 1955). 
Supreme Court has for a long time refused to accept Justice Holmes' suggestion in Ferry v. Ramsey ${ }^{10}$ that, in deciding how strong the rational connection must be between the basic facts and the presumed fact, the presence or absence of power in the legislature to make the basic facts a sufficient basis for imposing criminal liability is a relevant consideration. Indeed, the-Supreme Court's recent decision in Turner $v$. United States ${ }^{11}$ has now removed the possibility of any lingering doubts on this matter, for Turner was a case in which Congress clearly desired to reach both the basic fact-possession of narcotics-and the presumed facts which, in one instance, were receiving narcotics with knowledge that they were illegally imported and, in the other, distribution of narcotics other than in the original stamped package. ${ }^{12}$ The prohibition against the importation of heroin and other narcotics and the statutory presumption that one in possession of such narcotics has knowledge of their illegal importation originated in a 1909 statute. ${ }^{13}$ In 1914, this statute was supplemented by several revenue measures which included the precursor of the present prohibition against distributing heroin and other narcotics in other than the original stamped package. ${ }^{14}$ The 1914 legislation also imposed a prohibitive tax on the manufacture of smoking opium ${ }^{15}$ and a requirement that those engaged in the opium and cocoa leaf traffic register with the Government and pay an occupational tax. ${ }^{16}$ What might be called the "real" purpose of these "revenue" measures is revealed in one of the House Reports accompanying the 1914 legislation. The Report specifically states that, having already prohibited the importation of opium for nonmedical purposes, Congress was attempting totally to suppress the domestic manufacture of opium for smoking purposes by regulation of the domestic opium trade in what it considered to be the only

10. 277 U.S. 88 (1928).

11. 396 U.S. 398 (1970).

12. The statute, 26 U.S.C. $\S$ 4704(a) (1964), makes it a crime to "purchase, sell, dispense, or distribute," and the presumption operates with respect to all of these four possible violations. For conciseness, our discussion of the statute will employ the term "distribute," together with its adjectival and substantive forms, as a generic reference which includes the other aspects of the statute.

13. Act of Feb. 9, 1909, ch. 100, § 2, 35 Stat. 614 (1909), as amended, 21 U.S.C. $\S 174$ (1964).

14. Act of Dec. 17, 1914, 38 Stat. 785 (1914), as amended, 26 U.S.C. § 4704(a) (1964).

15. Act of Jan. 17, 1914, 38 Stat. 277 (1914), as amended, 26 U.S.C. \$ 4711 et seq. (1964).

16. Act of Dec. 17, 1914, 38 Stat. 785 (1914), as amended, 26 U.S.C. $\S 4701$ et seq. (1964). 
constitutional way-the imposition of a prohibitive tax on the manufacture of opium. ${ }^{17}$

This restricted view of the reach of the commerce power and the attendant need for Congress to rely on the customs and taxing powers to achieve its objectives now seems quaint. Most observers would think it too clear for argument that Congress now can prohibit the mere possession of narcotics. If anyone doubts that Congress is interested in punishing the mere possession of narcotics, he need only be referred to developments subsequent to Leary $v$. United States ${ }^{18}$ where the Supreme Court held that the statutory inference from the basic fact of possession of marijuana to the existence of the presumed fact, illegal importation, was not warranted. Congress has now indeed indicated that it wishes to take advantage of the expanded view of its power under the commerce clause to make possession of marijuana and other narcotics a crime. In recently enacted legislation, Congress has made possession of marijuana an offense. ${ }^{19}$ In so proceeding, Congress is only repeating the approach it took to the problem of LSD, mere possession of which has been a federal offense since $1965 .{ }^{20}$

17. H.R. ReP. No. 22, 63d Cong., 1st Sess. 2 (1913) (accompanying 38 Stat. 277 (1914), as amended, 26 U.S.C. $\S 4711$ et seq. (1964)). See also H.R. REP. No. 23, 63d Cong., Ist Sess. 3 (1913) (accompanying 38 Stat. 785 (1914), as amended. 26 U.S.C. $\$$ 4704(a) (1964)) where the commitment of the United States to the world wide suppression of the narcotics traffic is stressed, and it is again specifically stated that the only way the Congress could eliminate all but the "legitimate medical" traffic in narcotics was by the excrcise of its custom and taxing powers.

All these statutes were initially enacted, of course, in the days before Wickard v. Filburn, 317 U.S. 111 (1942), when it was thought that, under its power to make laws in the general welfare, Congress could only regulate people or goods actually moving in commerce. If it wished to impose a greater degree of regulation, Congress was forced to rely on its revenue powers as it actually did in the case of narcotics. In support of these revenue mcasures Congress could forbid distribution of narcotics in any container other than the original stamped package and try to make possession of narcotics in a packuge without tax stamps sufficient evidence of violation of such a statute. Beyond this, however, Congress could not go. Indeed, only a few years after being enacted, the statute imposing a regulatory tax on heroin narrowly escaped being declared unconstitutional as an attempt to invade the sphere of regulation reserved to the states under the transparent guise of being a revenue measure. United States v. Doremus, 249 U.S. 86 (1919).

18. 395 U.S. 6 (1969).

19. Comprehensive Drug Abuse Prevention and Control Act of 1970, Pub. L. No. 91 513, §§ 202(c), 404(a) (Oct. 27, 1970).

20. 21 U.S.C. $§ 321(v)(3)$ (Supp. IV, 1969), makes the possession of LSD punishable under 21 U.S.C. $\$ 360 \mathrm{a}(\mathrm{c})(1)$ (Supp. IV, 1969). The 1965 Act did this by permitting the Secretary of Health, Education, and Welfare to designate substances having a potential for abuse because of their hallucinatory effects, an authority which he exercised in $30 \mathrm{Fed}$. Reg. 13903 et seq. (1965), now appcaring as amended in 21 C.F.R. $\$ 320.3$ (c)(3) (1970). In 1968 Congress, in Pub. L. 90-639, specifically included reference to LSD in what is now 21 U.S.C. $\$ 321(v)(3)$ 
The new legislation repeals, as of May 1, 1971, the statutes involved in the Turner and the Leary cases, as well as the statute punishing the possession of LSD, and substitutes in their place one comprehensive law dealing with all aspects of a very large number of specifically mentioned narcotics and drugs. ${ }^{21}$ This legislation does not rely on any statutory presumptions of the type involved in Turner and Leary to assist the prosecution in proving its case; they are no longer necessary. 22

Nevertheless, the Court in Turner quite properly held that the existence of the presumed facts- "importation" or distribution other 'than in the "original stamped package"-must be proved beyond a reasonable doubt. ${ }^{23}$ Congress having so defined the crime, the Government was bound by that definition regardless of what Congress' underlying purposes might have been. Accordingly, the Court made clear that, with respect to facts which establish guilt or innocence, the sufficiency of the rational connection between the basic facts and the presumed fact must be judged by the "beyond a reasonable doubt" test. ${ }^{24}$ This result was certainly to be expected. In

(Supp. IV, 1969). In White v. United States, 395 F.2d 5 (Ist Cir. 1968), these provisions were upheld against the challenge that a federal prosecution thereunder, without an attempt to show any effect or connection with interstate commerce, was unconstitutional.

21. See Comprehensive Drug Abuse and Control Act of 1970, Pub. L. No. 91-513, §§ 40111,1101 (a), 1105(a) (Oct. 27, 1970).

22. Section 515 of the Act, id., creates certain typical affirmative defenses. Anyone asserting that his "possession" of prohibited items is lawful must prove that he comes within the statutory exemptions. Ashford and Risinger's discussion of affirmative defenses, which they analogize to presumptions, is examined at notes 58-69 infra and accompanying text. In discussing these limited aspects of the Act, it should not be inferred that we do not recognize the questionable features of the bill, such as the "no-knock" provisions. See $\S 509$ of the Act, id.

23. 396 U.S. 398 (1970). See also note 24 infra.

24. While Justice White's opinion for the Court is not as clear as one might wish, and while he declared that the 21 U.S.C. $\S 174$ presumption (knowledge of illegal importation with regard to cocaine) was not even more likely than not, his treatment of the 26 U.S.C. $\$ 4704$ (a) presumption (distribution other than in the original stamped package) leaves no doubt that the Court has adopted the "beyond a reasonable doubt" test. That presumption, with regard to cocaine, was struck down because there was a "reasonable possibility" Turner had either stolen the cocaine himself in the original stamped package or had obtained it from a stamped package in possession of the actual thief. 396 U.S. at 422-24. With regard to heroin, on the other hand, this presumption was upheld because "there is no reasonable doubt" that the heroin was not purchased from the original stamped package. Id. at 419-22. These holdings, together with the discussion upholding the 21 U.S.C. $\$ 174$ presumption with regard to heroin, id. at 407-18, where the Court held that the use of that presumption did not violate Turner's right to be convicted "only on a finding of guilt beyond a reasonable doubt," leave no doubt as to the effect of the Court's decision. See also In re Winship, 397 U.S. 358 (1970), where the Court applied the "beyond a reasonuble doubt" standard to certain factual determinations in juvenile court proceedings. 
March of 1969, the Committee on Rules and Procedure of the Judicial Conference of the United States had promulgated a preliminary draft of proposed rules of evidence for the United States district courts and magistrates. ${ }^{25}$ These rules, to which Ashford and Risinger do not advert, specifically provide that although proof of the basic facts may be regarded as sufficient evidence of the presumed fact, the existence of all facts-including presumed facts-that establish guilt or innocence or are elements of the offense charged or negative a defense must be proved beyond a reasonable doubt. ${ }^{28}$ Furthermore, the proposed rules also provide that the jury must be expressly informed that it may reject any statutory presumptions. ${ }^{27}$ These rules would hardly make sense if the Court, in Turner, had been unwilling to hold that the presumptions themselves must meet the "beyond a reasonable doubt" test. The proposed rules also provide that once the applicability of a presumption is defeated, it drops out of the trial. In the case of facts establishing guilt or innocence or elements of the offense charged, the presumption is defeated by the presence of evidence which the judge believes does not permit a reasonable juror, on the basis of all the evidence, to find the presumed fact beyond a reasonable doubt. ${ }^{28}$ Finally both Turner and the

25. Judicial Conference of the United States, Committee on Rules of Practice and Procedure, Proposed Rules of Evidence for the United States District Courts and Magistrates (Prelim. Draft March 1969).

26. See id. Rule 3.01. Since Ashford and Risinger only discussed presumptions in the context of facts "establishing guilt or innocence," we have restricted our discussion to facts of that nature. In criminal trials, facts which do nót come within these categories are normally required to be proved only by a preponderance of the evidence, the standard normally followed in civil actions. Accordingly, if a presumption were used to prove this type of fact, its validity would be judged by the same standard rather than the "beyond a reasonable doubt" standard.

27. Id.

28. See id. Rule 3.01(b). This provision is more favorable to the accused than the AL1 proposal under which the presumption is defeated when "the Court is satisfied that the evidence as a whole clearly negatives the presumed fact." ALI Model PEnal CODE $\$ 1.12(5)(a)$ (Proposed Off. Draft 1962). After Turner, the validity of the ALI proposal is very doubtful.

Presumably thu Judicial Conference's Proposed Rules will satisfy most of Ashford and Risinger's objections, Ashford \& Risinger 196-201, to the ALI proposals. We believe that CAL. Evid. CoDE $\S 607$ (West 1966), which they criticize for requiring the defendant to convince the jury of a reasonable doubt concerning the existence of the presumed fact, requires, almost of necessity, a preliminary judicial assessment similar to that contemplated under the federal proposals. Cf. CAL. Evid. Code $\$ 604$, Comment by Assembly Committce (West 1966). Indeed, when combined with the Turner requirements which will undoubtedly be imposed upon the states, see In re Winship, 397 U.S. 358 (1970), the new California rules-although not as favorable to the defendant as the proposed federal rules-meet most of Ashford and Risinger's objections to the use of presumptions. 
Advisory Committee's notes to the proposed federal rules make it clear that the particular verbal form in which a presumption is couched is not crucial. For example, the same results flow whether possession is made "prima facie evidence" or is made "sufficient evidence for conviction unless the defendant explains the possession to the satisfaction of the jury."29

The implications of our discussion thus far may be summarized as follows:

1. The Supreme Court has adopted, at least for the federal courts, several standards for the use of presumptions in criminal cases. A very strong rational connection which meets the "beyond a reasonable doubt" test must exist between the basic facts and the presumed fact. In addition, the burden of persuading the jury of the existence of the presumed fact must always be on the prosecution. It may reasonably be anticipated that the same standards will be applied in state criminal prosecutions, either as a result of voluntary adoption by the states or as a result of future decisions of the Supreme Court..$^{30}$

2. The high standards of proof with which the Court has surrounded presumptions, together with the expanded notions of the reach of congressional power, have considerably reduced whatever importance the use of presumptions might formerly have played in criminal prosecutions in the federal courts. ${ }^{31}$ The same conclusion might be in order with respect to criminal prosecutions in the state courts. One of the few almost universally recognized presumptions in the state courts is the jury instruction that, in a prosecution for the knowing possession of stolen goods, knowledge that the goods are stolen may be inferred from the unexplained possession of recently stolen goods. ${ }^{32}$ Typically, this so-called presumption is not the result of any legislative action but merely the result of a state supreme court's approval of a jury instruction to this effect or affirmance of a conviction in which the only evidence of knowledge was the

29. Both types of presumption received identical treatment in Turner. The Advisory Committee's Note to Rule 3.01, supra note 25, mentions several different verbal forms in which presumptions can be couched but which will be treated in an identical fashion.

30. See In re Winship, 397 U.S. 358 (1970), where the Court held that determinations of fact in certain state juvenile court proceedings must be based on the "beyond a reasonable doubt" standard.

31. See also Note, The Unconstitutionality of Statutory Criminal Presumptions, 22 StaN. L. REv. 341,354 (1970).

32. See, e.g., Stapleton v. Commonwcalth, 140 Va. 475, 124 S.E. 237 (1924). The same facts also give rise to a presumption that the possessor was the actual thief. Id. See also $9 \mathrm{~J}$. WIGMORE, EVIDENCE § 2513 (1940). 
unexplained possession of recently stolen goods. ${ }^{33}$ The only important issue involved here is whether a sufficient rational connection exists between the unexplained possession of recently stolen goods and the knowing possession of such stolen goods. For, whether or not the jury is instructed on the point, it is very likely to make this inference even if no specific reference is made to a presumption. Accordingly, even if all "presumptions" were struck down-a position that Justice Black advocated in Turner ${ }^{34}$-because they place the burden of coming forward on the defendant and because they deny the defendant the right to have the evidence on which he may be convicted presented to the jury, the defendant is still confronted with the same dilemma. If the jury is likely to convict him on the basis of the evidence of recent possession that has been presented by the prosecution, he will have to come forward with evidence, regardless of his constitutional right to remain silent. The situation is not like that in a narcotics prosecution where the jury is told that, from unexplained possession, it may infer that the narcotics were distributed in a package not bearing tax stamps or were illegally imported-something that would not ordinarily occur to the jury. ${ }^{35}$

3. The courts have never recognized Ashford and Risinger's second requirement concerning the use of presumptions in criminal prosecutions: namely, the requirement that there must be a very high probability that an innocent defendant will be able to introduce evidence sufficient to defeat the applicability of the presumption. This second requirement raises some important philosophical questions about the nature of the legal process, and it is to these questions that we now turn.

11.

The second constitutional requirement that Ashford and Risinger suggest should be imposed upon the use of presumptions in criminal trials is premised on the false assumption that the overriding purpose

33. 9 J. Wigmore, supra note 32, § 2513. See, e.g., Stapleton v. Commonwealth, $140 \mathrm{Va}$. 475, 124 S.E. 237 (1924).

34. Turner v. United States, 396 U.S. 398, 425, 430-33 (1970). See also 22 STAN. L. REv., supra note 31 , at $351-52$, which is particularly concerned that the use of presumptions permits a defendant to be convicted without the presentation of all the evidence to the jury. This Note unfortunately devotes only a brief section to Turner, id. at 352-53, undoubtedly because thc decision was handed down while the Note was in its final stages of preparation. We shall discuss, in Part IV infra, some underlying practical considerations which should be taken into account when considering the role of presumptions in criminal trials and the desirability of abolishing their use.

35. A frequently used statutory presumption in the state courts is one making possession of 
of criminal procedure is to prevent, if possible, the conviction of any innocent defendants. Of course, the criminal process in any civilized society is designed to protect the innocent. This concern is often expressed in the aphorism that it is better that " $5(?), 20(?)$, or $100(?)$ guilty men should go unpunished than that one innocent man should be convicted." 36 In adopting the requirement that an accused may not be convicted unless the trier of facts is convinced of his guilt beyond a reasonable doubt, the criminal law is surely demonstrating its concern for the protection of the innocent. But two things must be noted ab out "the "beyond a reasonable doubt" standard. First, its adoption amounts to a flat rejection of the doctrine that it is better that all guilty men should go unpunished than that any innocent men, or even that as few innocent men as possible, should be punished. Second, and much more important, once a standard such as the "beyond a reasonable doubt" standard is adopted, it necessarily acquires a dynamic logic of its own which, in some of its aspects, will not always be consistent with some of the basic underlying purposes of the standard.

McCoy v. United States ${ }^{37}$ provides a graphic illustration of this last assertion. In $\mathrm{McC}$ oy, the defendant, in a felony case, tried to plead guilty at the close of the Government's evidence to a related misdemeanor for which the maximum possible penalty was six months in jail. By this stage of the trial, the evidence against the defendant was sufficient for the case to go to the jury on the felony charge. When the defendant rose to change his plea to guilty after consultation with counsel and the trial judge, the judge asked him all the prescribed questions designed to determine whether the defendant appreciated the nature and the inevitable consequences of his action. The defendant made all the stock replies. Before the trial judge accepted the plea, however, he asked the defendant "one more question."

The Court:

The Defendant: Did I take somebody's property?

burglary tools prima facie evidence of the statutory crime of possession of burglary tools with intent to commit burglary. The main problem here is in defining what "burglary tools" are. See Benton v. United States, 232 F.2d 34 I (D.C. Cir. 1956).

36. Toward the end of the 17th century, Matthew Hale used the ratio of five to one. Blackstone raised it to ten to one. In the late middle ages, Sir John Fortescue favored a twentyto-one ratio in capital cases. See Fletcher, Two Kinds of Legal Rules: A Comparative Study of Burden-of-Persuasion Practices in Criminal Cases, 77 Y ALE L.J. 880, 88 1-82 (1968).

37. 363 F.2d 306 (D.C. Cir. 1966). 
The Court: Did you take their property without right-in this casc an automobile?

The Defendant: No, sir. ${ }^{33}$

The judge advised the defendant that the court could not allow him to plead guilty if he had not taken the property in question. This colloquy followed:

The Defendant: Your Honor, if I am willing to plead to this lesser charge, could I plead?

The Court: You can't plead before me to a charge to which you say you are not guilty. No sir, you cannot do that. ${ }^{39}$

Following the return of the jury, the trial proceeded and the defendant was ultimately convicted of the felony and sentenced to eight months to three years in jail. The conviction was affirmed on appeal by a somewhat embarrassed court of appeals. The appellate court expressly stated, however, that trial judges are not required to inquire into a defendant's reasons for pleading guilty..$^{40} \mathrm{Trial}$ courts should, of course, make sure that the defendant has the capacity to and does appreciate the nature and the consequences of his guilty plea. They should also consider whether significant evidence of guilt is available. Beyond that, however, trial courts should not go. A defendant is not obliged to concede his guilt or the inevitableness or correctness of an eventual'jury verdict. ${ }^{41}$

The Supreme Court's opinion in McCarthy $v$. United States ${ }^{42}$ did not detract from the soundness of this position. In McCarthy the Court quite properly held that the proper and efficient administration of justice requires literal compliance with the mandate in Rule 11 of the Federal Rules of Criminal Procedure ${ }^{43}$ that the trial judge address the defendant personally to ascertain whether he understands the nature of the charges and the consequences of the plea; the judge cannot substitute the assurance of counsel for a personal examination of the defendant. ${ }^{44}$ The Court in McCarthy also adverted to the

\footnotetext{
38. Id. at 307.

39. Id.

40. Id. at 307-08.

41. Id. A few years after the $M c C$ oy case, the same court of appeals reversed a conviction for second degree murder after the trial judge refused to accept a plea of guilty to manslaughter because there were inconsistencies in defendant's statement which suggested the possibility of "self-defense." Griffin v. United States, 405 F.2d 1378 (D.C. Cir. 1968).

42. 394 U.S. 459 (1969).

43. Fed. R. Crim. P. I1. •

44. Cf. Boykin v. Alabama, 395 U.S. 238 (1970), where the Court held that guilty pleas in
} 
importance of fulfilling Rule 1l's further requirement that the trial judge make certain that some factual basis for the plea is present. Writing for the Court, Chief Justice Warren indicated his approval of the Advisory Committee on Criminal Rules' suggestion that this requirement could be met in three ways: inquiring of the defendant; inquiring of the prosecution; and examining the presentence report. ${ }^{45}$ The McCarthy case, however, is no warrant for concluding that the trial judge must be convinced that the defendant actually is guilty before accepting the plea. Any possible doubt on this score was eliminated by the rationale of the Court's recent decision in North Carolina v. Alford. ${ }^{46}$ Indeed, any other resolution of the problem would have transformed cases which exhibit a pressing concern with fairness toward the defendant into sterile academic exercises that are indifferent to the actual problems that confront criminal defendants. ${ }^{47}$

The most difficult case, of course, is one where the defendant earnestly wishes to make a guilty plea for which there is a factual basis but, at the same time, maintains that he did not commit the criminal act in question. The notes to the American Bar Association's Standards Relating to Pleas of Guilty unfortunately devote only one sentence to the problem, concluding that "if the defendant is called upon to make a statement and he denies commission of the offense,

state courts will be upheld only if the record affirmatively shows that they were intelligently and voluntarily made.

45. 394 U.S. at 463 n.6.

46. 39 U.S.L.W. 4001 (U.S. Nov. 23, 1970). Even the three dissenters, in an opinion by Justice Brennan, were not prepared to hold that a guilty plea could never be accepted if the defendant persisted in denying his guilt. Id. at 4005 . Justice Brennan had previously indicated his unwillingness to adopt so extreme a position in his concurrence in Brady v. United States, 397 U.S. 742 (1970), where he agreed that Brady's guilty plea was not open to collateral attack because there was "no indication, contemporaneous with the ... plea, that Brady thought he was innocent and was pleading guilty merely to avoid possible execution." Id. at 816 (emphasis added). Brady was a collateral attack on a conviction entered upon a guilty plea under the federal kidnapping act. The collateral attack was prompted by United States v. Jackson, 390 U.S. 570 (1968), which struck down that portion of the act which permitted the jury to impose the death penalty and hence operated to encourage defendants to waive their rights to a jury trial in order to be tried by the judge who had no authority, under the act, to impose the death penalty.

47. Since a defendant who pleads guilty under the circumstances being discussed is not even arguably perpetrating a fraud on the court, the proscriptions of the ABA's ethics code relating to preservation of confidences and secrets of a client and representing a client within the bounds of the law are not applicable. See ABA Code of Professional Responsibility DR 4$101(C)(2) \& 7-102(B)(2)(1969)$. Morcover, the propriety and even constitutionality of these rules are questionable insofar as they require a lawyer to reveal the confidences of a criminal defen- 
then, notwithstanding the existence of other information tending to verify the accuracy of the plea, it would be inappropriate for the judge to enter the plea." 48 The major authority cited for this proposition is the $M c C o y$ case which, although relevant to the issue, can hardly be said to support so sweeping a proposition. The only other case referred to in the notes supports a position contra to that taken by the ABA. ${ }^{49}$ Only slightly less cryptic and somewhat uncoordinated with the Standards Relating to Pleas of Guilty on this issue, the ABA's Proposed Standards Relating to the Prosecution Function and the Defense Function provide that if an accused discloses to his lawyer facts which negate guilt and the lawyer's investigation does not reveal a conflict with the facts disclosed by his client, the defense lawyer may not properly participate in presenting a plea of guilty without disclosure of such facts to the court. Presumably, this standard applies regardless of how certain the lawyer is that his client will be convicted of a more serious charge. ${ }^{50}$ At the same time, prosecutors are admonished not to acquiesce in a plea of guilty when the accused maintains his innocence unless a complete disclosure is made to the court. ${ }^{51}$ Such complete disclosure, however, would then trigger the application of the ABA's Standards Relating to Pleas of Guilty to

dant whom the lawyer is representing. The Code of Professional Responsibility does not explicitly attempt to meet any of the arguments raised in ABA Opinion 287, which reached a diametrically opposite conclusion. See also New York County Opinion 259 (1928). Both opinions are reprinted in V. Countryman \& T. Finman, The LAWYeR IN MOdern Society 232-37 (1966).

48. A Ba Standards Relating to Pleas of Guilty $\$$ 1.6, Commentary at 34 (Approved Draft 1968).

49. See Maxwell v. United States, 368 F.2d 735, 739 n.3 (9th Cir. 1966). The court did note that the case before it arose before the adoption of Rule 11 of the Federal Rules of Criminal Procedure expressly required that the trial court find a factual basis for the plea. 1t is presumably because of this caveat that the case is cited, witb the signal " $c f$." in support of the ABA position. For a more complete set of citations to the relevant cases on the issuc, see the majority and dissenting opinions in North Carolina v. Alford, 39 U.S.L.W. 4001 (U.S. Nov. 23, 1970). See also note 50 infra.

50. A Ba Standards Relating to the Prosecution function and the Defense Function $\S 5.3$ (Tent. Draft 1970). See also Commentary, id. at 241 . In recognizing that the defense lawyer is not completely bound by the aecused's view of the facts, this provision is at least less rigid than the position taken in the Commentary to the $A B A$ Standards Relating to Pleas of Guilty. supra note 48 , at 34 , with which it is also somewhat inconsistent.

51. A Ba Standards Relating to the Prosecution Function and the Defense Function $\S 4.2$ (Tcnt. Draft 1970). See also Commentary, id. at 107. 
preclude the court from accepting the plea, even in a case where the court was certain that the jury would find the defendant guilty of a more serious offense and that the defendant was completely deluded in believing that he was "really" innocent. This cursory disposition in the ABA's Standards is much too glib a treatment of a very serious problem. While no one wants to see innocent people convicted, neither should one be indifferent to the fact that, from the defendant's point of view, five years in jail is better than fifteen. To adopt supposedly rigorous, formal requirements that will be disregarded in practice-because judges avoid raising the question, defendants know better than to be candid if they are asked, and lawyers simply ignore the standards-is to close one's eyes to reahty. ${ }^{52}$ Surely this area requires more honest and critical thought before a definitive position is taken. ${ }^{53}$ Fortunately, the Court in Alford has now held that the Constitution does not require any such simplistic approaches to the problem.

McCoy's case and now Alford's case highlight a very serious theoretical issue. As we have seen, in the excerpts from his colloquy with the trial judge, the issue confronting McCoy was not whether he was guilty or innocent but whether a reasonable jury would believe, beyond a reasonable doubt, that he was guilty. These are obviously different questions, and a rigid formalism which, in the name of truth, refuses to recognize the differences is unjust. A rational man must accommodate himself to the dynamics of the "beyond a reasonable doubt" test. If it is likely that a jury will believe, beyond a reasonable doubt, that he is guilty, he must do something about the situation. His knowledge that he really is innocent, that the burden of persuasion is on the prosecution, and that "plea bargaining" with innocent defendants is frowned upon by people who are unlikely ever to be defendants in criminal cases will provide scant consoiation to him. If he has a prior conviction which can be used to impeach his veracity should he decide to appear as a witness on his own behalf, his

52. See Weinberg \& Babcock, Book Review, 76 Y Ale L.J. 568 (1967). This review of D. Newman, Conviction: The Determination of Guilt or innocence Without Trial (1966), focuses on the important considerations involved from the defense lawyer's viewpoint. The book itself examines the institutional use of guilty pleas in the criminal process from the point of view of the criminologist. More such useful work is obviously needed to compile meaningful statisties. Naive academic assumptions that a defendant is always better off in having a jury assess his guilt or innocence are not an acceptable substitute. See Note, The Unconstitutionality of.Plea Bargaining, 83 HARV. L. REV. 1387 (1970).

53. Sce note 49 supra. 
position will be particularly desperate. Lest we appear cynical, we should stress that any standard of proof occasionally imposes this sort of dynamic on the criminal process, making guilt or innocencethe factor the criminal process ostensibly is designed to establishlargely irrelevant. The criminal process may avoid this dilemma only by imposing the formal standard that only guilty people can be convicted and enforcing the standard by not convicting anyone.

Presumably to meet this problem, Ashford and Risinger propose that presumptions may be used only upon a showing of two factors: a rational connection between the basic facts and the presumed fact, and a high probability that innocent defendants will be able to defeat the application of the presumption. ${ }^{54}$ The logic of this suggestion surely requires, in addition, that every other inference open to a jury must meet this test-for most inferences which the jury must make in a criminal trial have not been institutionalized as presumptions and yet, from the defendant's point of view, are just as important. This same logic also requires that, in criminal cases, not only must the jury believe the defendant guilty beyond a reasonable doubt before returning a verdict that the defendant is guilty-which is also an inference- $b u t$, in every class of case in which the test is applied, the likelihood that an innocent defendant will be convicted must also be low. For while the "beyond a reasonable doubt" test is designed to insure against the conviction of innocent defendants, in practice it may allow the conviction of a significant number of innocent defendants in some types of situations.

Unfor tunately, however, Ashford and Risinger's suggested supplementation of the "beyond a reasonable doubt" test would be unable to achieve its objective. First, it cannot be applied in practice. As Ashford and Risinger seem to recognize, ${ }^{55}$ the test must be quantified to be meaningful, and this cannot be done. How can one possibly determine the percentage of innocent persons who will be unable to defeat the operation of a presumption or any other inference, including the inference of guilt from a belief in guilt bcyond a reasonable doubt, to which they are subject? The relevant factors are not only unmeasurable; they are also incommensurate, involving questions of so-called "objective fact" and subjective evaluations of the availability and competency of counsel. Second, even if by some miracle it were possible to quantify the relationship between innocence and the ability to overcome a presumption or any other

54. Ashford \& Risinger 180-86.

55. Id. at 183. 
inference, such quantification does not determine that any particular defendant will overcome the presumption. It only tells us that it is rational to believe that he will-a completely different matter. Nor would such quantification necessarily reveal very much about how our criminal process operates in the "long run." If quantification of probabilities disçloses anything about the real world, it is that, when a sufficiently large number of instances is considered, the predicted statistical correlation will be seen to exist. In practice, this means that it is very likely that a sample consisting of a very large number of instances will achieve a eertain degrce of proximity to the predicted statistical correlation. Given the small number of sufficiently similar instances that ever reach the courts in many areas of the law, the most that one can often compute is the likelihood that a sample containing that number of instances will come within a certain degree of proximity to the expected statistical correlation. ${ }^{58}$ The only way to make sure that innocent people will be able to defeat the presumptions and other inferences made against them-and one cannot distinguish presumptions from other inferences in this regard-is to make it impossible to convict anyone.

In short, while Ashford and Risinger's theory is prompted by praiseworthy motives, it ignores the dynamics of the criminal process and, given its preoccupation with actual guilt or innocence, could actually lead to misguided trial tactics. It could not possibly be applied in the real world; and, even if it could, it would not come as close to solving the problem as Ashford and Risinger think. Certainly, important things can and should be done to decrease the possibility of convicting innocent defendants. ${ }^{57}$ Meaningful reform will not be accomplished, however, by an excessive preoceupation with formal requirements divorced from the concrete realities of the legal process.

111.

The most controversial part of the theoretical framework proposed by Ashford and Risinger is the extension of their analysis of

56. For example, the general class of defendants in prosecutions under 26 U.S.C. $\$ 4704(a)$ (1964), is not precise enough for aecurate statistical correlations. Defendants under this statute could be white or black, first or multiple offenders, rich or poor, all these factors would be relevant to their chances of success. Sucb a class is unlike the situation where blood types are used to help determine paternity, and statistics on a large number of people are easily obtainable because everyone is a member of the relevant classes. For a discussion of the meaning of probability statements see R. BRAIthWAITE, SCIENTIFIC EXPLANATION (1960).

57. Some possible measures are discussed in notes 71-90 infra and aecompanying text. 
presumptions to what they call assumptions, a category usually referred to as affirmative defenses. Affirmative defenses can profitably be called assumptions because they not only shift the burden of coming forward with evidence to the defendant, as do presumptions, but they also shift the burden of persuasion from the prosecution to the defendant. ${ }^{58}$ Under Ashford and Risinger's proposal, the state can validly impose the burden of persuasion upon the defendant only upon proof that:

1. A strong rational connection exists between the other elements of the offense (A and B) and the negative of the so-called affirmative defense (-X); and

2. The probability that an "innocent" defendant will be unable to prove the affirmative defense $(X)$ is very low.s"

With all deference, we must submit that this proposal is extremely ill-advised. What gives the proposal some plausibility is, undoubtedly, the fact that many so-called affirmative defenses arose at common law purely as a matter of convenience. Innumerable exceptions existed to the crimes recognized at common law. Since most of these exceptions were not applicable in the usual situation, and the defendant was particularly able to know if they were present in his case, it made a great deal of sense to place the burden of coming forward on the defendant. Most so-called affirmative defenses at common law do no more, and they are therefore not properly instances of what Ashford and Risinger call assumptions. ${ }^{\circ}$ From this, the imposition of the burden of.persuasion upon the defendant in a few instances was not a very great step. Accordingly, if these "true" common law affirmative defenses relate to elements of the crime, it seems very sensible to impose at least the first requirement suggested by Ashford and Risinger-a strong rational connection between the

58. In point of fact, few of the generally recognized "affirmative defenses" actually shift the burden of persuasion to the defendant. Among the few are duress and, at common law, insanity. In most jurisdictions, the majority of so-called affirmative defenses such as self-defense and alibi merely impose a burden of coming forward with evidence on the defendant. Affirmative defenses of this second kind really operate in the same manner as do presumptions and, if they pertain to what are considered elements of the offense charged, should be judged by the same standards as are presumptions. Most true affirmative defenses are specifically included in the statutes establishing the crime to which they are apphicable. See, e.g., Comprehensive Drug Abuse Prevention and Control Act of 1970, Pub. L. No. 91-513, § 515 (Oct. 27, 1970). See generally C. MCCormick, Evidence 683-84 (1954); 9 J. Wigmore, Evidence $\S \S 2512$ \& 2514 (3d ed. 1940); Ali Model Penal Code $\S 1.13$, Comments at 108-14 (Tent. Draft No. 4, 1955).

59. Ashford \& Risinger at 189-93.

60. See note 58 supra. 
other elements of the offense charged and the negative of the affirmative defense-even after the threshold question of comparative convenience has been strongly decided in favor of putting the burden of persuasion on defendant. Since the 19th century, however, the trend has been away from the fragmentarily defined crimes of the common law and toward comprehensive statutory definitions of crimes in which the legislature attempts to state clearly the elements of the offense and the factors which may be considered either in exculpation or mitigation of guilt. In many such cases, the legislature can be said to have meant what it said. The offense it wished to punish consists of those elements of which the prosecution has the burden of persuasion. The category of affirmative defenses is merely an instance of legislative grace which it may grant or withhold in its discretion. In this case, it is not at all clear why the strong rational connection test should be applicable. Indeed, many important reasons suggest that it should not.

Consider, for example, the "affirmative" defense of insanity. This defense is discussed by Ashford and Risinger ${ }^{61}$ in the context of Leland $v$. Oregon, ${ }^{62}$ a case of which they strongly disapprove. In response to a charge of murder in the first degree, the defendant had raised the defense of insanity. Oregon law at that time placed the burden of persuasion coneerning insanity on the defendant, requiring him to prove his insanity "beyond a reasonable doubt." The Supreme Court of the United States affirmed, with only Justices Frankfurter and Black dissenting. The case is disquieting for two related reasons. First, in requiring the defendant to prove his insanity beyond a reasonable doubt, Oregon had departed from the common law practice of requiring affirmative defenses to be proved only by a preponderance of the evidence. At common law, only the prosecution was ever required to meet the "beyond a reasonable doubt" test. The Orcgon statute was unique, in this regard, in the English-speaking world ${ }^{63}$ and has since been repealed. ${ }^{64}$ The Leland case is also contrary

61. Ashford \& Risinger at 202-03.

62. 343 U.S. 790 (1952).

63. Id. at 798 (Frankfurter, J., dissenting). MoCormick called the statute "extraordinary." C. MCCoRmick, supra note 58 , at $684 \mathrm{n} .26$. The only other reference by either Wigmore or MoCormick to any instance in which the burden of persuasion with respect to an affirmative defense required proof beyond a reasouable doubt is to State v. Scott, 49 La. An. 253, 21 So. 271 (1897), where the Louisiana court overruled a prior case that had imposed the burden of proving insanity upon the defendant in accordance with the "beyond a reasonable doubt" standard. $9 \mathrm{~J}$. WiGMORE, supra note $58, \S 2501$, at 361 n.1.

64. Ore. Rev. Stat. $\S 136.390$ (1955). Oregon now requires the defendant to prove his 
to the growing belief that a state must recognize insanity as a defense to a crime. This. belief finds some support in the fact that most states have now departed from the common law practice of placing the burden of persuasion on the issue of insanity on the defendant and have adopted the federal practice of requiring the prosecution to prove the absence of insanity beyond a reasonable doubt. ${ }^{65}$ Under this practice, the only burden remaining on the defendant is to put the question of insanity in issue. Insanity is, strictly speaking, then, no longer an "affirmative" defense.

Let us assume, however, as indeed we must, that there are many possible defenses to crimes that the legislature is not constitutionally bound to recognize. Why should there be a strong rational connection between the elements of the offense, $\mathrm{A}$ and $\mathrm{B}$, and the negative of the affirmative defense, $-X$ ? The same objection can be raised, with even greater force, against Ashford and Risinger's second requirement for the use of affirmative defenses, namely a high probability that "innocent" defendants will be able to prove $X$, the affirmative defense. Leaving aside the very serious problems with this second requirement that have already been discussed in connection with presumptions, why must the legislature consider a man, against whom elements A and B have been established beyond a reasonable doubt, as "not worthy of punishment?" Why cannot the legislature regard him as worthy of punishment but still deserving of a chance to show why he should not be punished in this case? This is not like the case of presumptions where the legislature has chosen to include an element, $\mathrm{Y}$, in the description of those who are worthy of punishment. In that case, it is only proper that the existence of element $Y$ should be established by the prosecution in accordance with the "beyond a reasonable doubt" standard..$^{\text {b6 }}$ If the legislature wanted to remove element $Y$ from consideration on the question of guilt, it should have said so. But in the present situation, the legislature has said that proof of elements A and B is sufficient for imposing punishment on the defendant. If the legislature has constitutional power to make an offense out of elements A and B, it is ridiculous to say that it cannot make another element, $\mathrm{C}$, an exculpatory factor unless it is highly

insanity by a preponderance of the evidence. Law of May 31, 1957, ch. 380, 1 [1957] Ore. Laws 507.

65. Cf. 343 U.S. at 798. The federal standard was adopted in Davis v. United States, 160 U.S. 469 (1895).

66. See text accompanying.notes 10-24 supra. 
probable, more probable, or even probable either that not $-\mathrm{C}$ is the case or that a defendant will be able to prove $C$, if in fact $C$ is the case. Consider, for example, a statute which prohibits the discharge of a firearm in a public place but allows the defendant to escape liability if he can prove that he had not intended to harm anyone. A requirement of either a strong rational connection between discharging the firearm and intending to harm someone or of a high likelihood that a defendant who really had not intended to harm anyone would be able to convince a jury of that fact would be difficult to justify. Ashford and Risinger would, of course, impose both requirements and, if the requirements were not met, would strike down the statute. To avoid the unfortunate consequences of this result, would they permit the state to define a crime in terms of elements $A$ and $B$ and then to make element $C$, the burden of persuasion of which is on the defendant, relevant only to the question of punishment? Or would they say that this too is improper? Certainly, from the point of view of the defendant, making $\mathrm{C}$ an affirmative defense to the crime is preferable, since the defendant can avoid the stigma of conviction if he is successful. But even the second alternative is better than ten years in jai]. To shackle a legislature by limiting its options in the ways Ashford and Risinger suggest may lead to the legislature's refusal to recognize any defense at all, "affirmative" or otherwise. This triumph of form over substance leaves the defendant materially worse off.

Consider, again, the case of insanity and assume even that the state is constitutionally required to recognize the "defense" of insanity. At the present time, a state could constitutionally adopt the strict $M^{\prime}$ Naughten $^{67}$ standard, requiring a determination of whether the accused "was laboring under such a defect of reason, from disease of the mind, as not to know the nature and quality of the act he was deing or, if he did know it, that he did not know he was doing what was wrong," and place the burden of persuasion of proving sanity upon the prosecution in accordance with the "beyond a reasonable doubt" test. A state might, on the other hand, wish to adopt the Durham"s "product of a mental disease" test" and place the burden of persuasion, "by a preponderance of the evidence," upon the

67. M'Naughten's Case, 8 Eng. Rep. 718,722 (H.L. 1843).

68. Durham v. United States, 214 F.2d 862 (D.C. Cir. 1954).

69. The standard was first adopted in New Hampshire in the ninetcenth century. See State v. Pike, 49 N.H. 399, 408 (1870); State v. Jones, 50 N.H. 369, 398 (1871). Both cases were relied on in Durham. See 214 F.2d at 874-75. 
defendant, thereby creating an "affirmative" defense. It would not be unrealistic to expect that fewer "innocent" or "insane" defendants will be convicted under the first set of definitions and procedures than under the second; but any theoretical formulation which forces a state to favor the first alternative, because of its greater "formal" validity, is subject to justifiable ridicule. Whatever the relevant formal considerations might be, a rational defendant and a rational defense lawyer might very well prefer the second alternative in the not irrational belief that more defendants will be found "insane" under this test. The same sort of practical considerations also suggest that removal of the issue of sanity to a separate proceeding in which the disposition of the convicted defendant is the sole issue might not necessarily be a preferable one from the defendant's point of view, however formally satisfying it might be to some theorist, because all the burdens of persuasion are placed on the state.

Formalization of legal theory is only a means of achieving justice. It is not an end itself. A theory formally designed to protect the "innocent" defendant might, in practice, provide less protection to actual defendants than would a more flexible but ostensibly less morally justifiable theory. The pursuit of truth to the exclusion of other considerations can lead not only to no convictions-it can lead to too many. Justice and rationality are not, of course, incompatible values. Rationality, however, must be determined in the light of the overall goals of social institutions. Excessive preoccupation with the rationality of one component can be irrational when judged from the point of view of the entire scheme of institutional arrangements in a particular society. We submit that this is the case here. At any rate we are surprised that Ashford and Risinger were unwilling even to consider these broader questions.

IV.

Our criticism of the Ashford-Risinger analysis of presumptions should not suggest indifference to the practical effects of presumptions in many criminal cases. Too often, an obligation is placed on defendants to come forward with evidence in circumstances where they have little possibility of meeting the burden. It is doubtful if many innocent defendants are convicted, but the possibility of a miscarriage of justice cannot be ignored, particularly when the difficulty of rebutting a presumption is combined with a system of 
differential leniency in sentencing in a manner which provides institutionalized encouragement for guilty pleas. ${ }^{\text {To }}$

Our concern is that Ashford and Risinger propose an unrealistic cure that may be worse than the disease when the plight of the innocent defendant can be remedied more effectively by other techniques which stand a better chance of being adopted. In many-if not most - cases the problem is not the existence of a high probability that innocent defendants as a class will be unable to challenge sufficiently the existence of the presumed fact. The difficulty is that a particular defendant under indictment may lack the resources to produce favorable evidence concerning the basic or presumed facts because of three deficiencies in existing criminal procedure: the inadequacy of criminal discovery which may prevent the defendant from knowing what evidence will be used against him until trial and which may deny him access to evidence favorable to his cause even at trial; the absence, in many cases, of funds for investigation or for securing expert witnesses; and the unwillingness, sometimes encouraged by the government, of witnesses to discuss the case with defense counsel before trial. These handicaps could affect the presentation of the defense in any criminal case, but their significance is likely to be magnified when presumptions are involved. This combination of the inadequacy of formal discovery, the uncooperative government witness, and the absence of resources for independent factual investigation seem, therefore, the most appropriate target upon which those who are genuinely concerned with the protection of the innocent defendant should concentrate their efforts.

Criminal discovery in the federal courts provides an example of the kind of reform that is necessary. Under the present rules, a defendant, upon a proper showing, may discover books, papers, documents, tangible objects, buildings or places, or copies or portions

70. The ABA Project on Minimum Standards for Criminal Justice Standards Relating to Pleas of Guilty has assumed that "conviction without trial will and should continue to be a most frequent means for the disposition of criminal cases." ABA Standards Relating to Pleas of GuilTy 2 (Approved Draft 1968). In its opinion, the existing plea bargaining system which produces a high percentage of guilty pleas "cannot operate effectively unless trial judges in fact grant charge and sentence concessions to most defendants who enter a plea of guilty. . . ." For this reason, the standards affirm the propriety of courts granting charge reductions or sentencing concessions when the public interest in the effective administration of justice would thereby be served. Id. at 38. In substance this means leniency is encouraged for pleas of guilty. Differential leniency apparently is constitutionally permissible. McMann v. Richardson, 396 U.S. 1034 (1970); Brady v. United States, 396 U.S. 809 (1970). See also North Carolina v. Alford, 39 U.S.L.W. 4001 (U.S. Nov. 23, 1970). 
thereof that are within the control of the government.$^{71} \mathrm{He}$ may also discover written or recorded statements or confessions made by the defendant within the control of the government and the recorded testimony of the defendant before the grand jury. ${ }^{72}$ ln addition, a defendant can obtain access to the results or reports of physical or mental examinations and of scientific tests or experiments made in connection with his case, again when they are within the control of the government. ${ }^{73}$ ln a capital case, he is also entitled to the names of government witnesses three days before trial. ${ }^{74}$ Finally, the case law warns the government that the suppression of evidence favorable to an accused, if he has requested it, violates due process, irrespective of the good or bad faith of the prosecution. ${ }^{75}$ The matters immune from discovery under the present law are much more impressive, however, and include evidence and leads which may be crucial to counsel obliged to combat a presumption. Specifically, the weight of authority would now deny a defendant access to the statements of a co-defendant, ${ }^{76}$ the names of government witnesses in non-capital cases, ${ }^{77}$ the names of persons having information concerning the offense whom the government does not plan to call, ${ }^{78}$ his own record of prior convictions, ${ }^{79}$ and the record of prior convictions of government witnesses. ${ }^{80}$

In a prosecution for a narcotics offense a defendant may therefore be'less concerned with the abstract effect of presumptions arising from possession than with his inability to ascertain the identity of the informant before trial, his inability to cross-examine an informant effectively on the basis of prior convictions, while facing impeachment if he chooses to testify, ${ }^{81}$ his inability to ascertain the

71. FED. R. CRIM. P. 16(b).

72. Id. 16(a).

73. Id.

74. 18 U.S.C. § 3432 (1964).

75. See Giles v. Maryland, 386 U.S. 66 (1967); Brady v. Maryland, 373 U.S. 83 (1963).

76. United States v. Edwards, 42 F.R.D. 605 (S.D.N.Y. 1967); United States v. Turner, 274

F. Supp. 412 (E.D. Tenn. 1967).

77. United States v. Chase, 372 F. 2d 453 (4th Cir.), cert. denied, 387 U.S. 907 (1967); United States v. Tanner, 279 F. Supp. 457 (N.D. 111. 1967); United States v. Westmoreland, 41 F.R.D. 419 (S.D. Ind. 1967).

78. United States v. Chase, 372 F.2d 453, 466 (4th Cir. 1967).

79. Cf. Proposed amendments to Federal Rules of Criminal Procedure for the United States District Courts Rule 16(a)(1)(iii) (Prelim. Draft, 1970).

80. Hemphill v. United States, 392 F.2d 45 (8th Cir.), cert. denied, 393 U.S. 877 (1968).

81. Cf. District of Columbia Court Reform and Criminal Procedure Act of 1970, Pub. L. No. 91-358, § 133 (Oct. 27; 1970), overruling case law whieh limited use of convictions to impeach defendants in criminal cases. See Luck v. United States, 348 F.2d 763 (D.C. Cir. 1965). 
identity or whereabouts of other witnesses not called by government, or his inadequate knowledge of what a co-defendant has told the police. The effect of a presumption is much different in this setting than where such information is routinely made available to a defendant. Indeed present limitations upon discovery may make it impossible for defense counsel to make a reasoned decision of whether to recommend a plea of guilty or advise his client to testify if he goes to trial. Effective cross-examination will be the exception rather than the rule.

Fortunately, the law's niggardly attitude toward criminal discovery is now in the process of revaluation. The proposals of the A merican Bar Association's Project on Minimal Standards for Criminal Justice ${ }^{82}$ and the recent proposed amendment to the Federal Rules of Criminal Procedure ${ }^{83}$ are indicative of a changed attitude which will go far toward permitting defendants to rebut presumptions effectively where there is evidence to support their contentions.

Criminal discovery directed against the government is an effective investigating tool only when the government has control, possession, or custody of the information which is sought. It can not be more efficient than the government's own investigation. A defendant should be able to investigate a case effectively without the necessity of relying upon the government. In a minority of cases where financial resources do not constitute a problem, effective defense investigations are possible. But, in most cases, the resources of the defendant will be inadequate to investigate a case properly, and, in the case of an indigent who cannot obtain pretrial release, the task may prove to be beyond the capacity of even the most devoted counsel. The need can be met by government subsidized investigative services, provided either by a permanent staff ${ }^{84}$ or made possible through the allocation of funds which permit the hiring of investigators for special cases ${ }^{85}$ and by reimbursement to defense attorneys for out-of-pocket costs incurred in conducting their own investigations. ${ }^{88}$ Funds should also be

82. ABa Standards Relating to Discovery and Procedure Before Trial (Tent. Draft. 1969).

83. See Proposed Amendments to Federal Rules of Criminal Procedure for the United States District Courts Rule 16 (Prelim. Draft, 1970). See also 1 C. Wright, Federal Practice \& Procedure §§ 252-54 (1969).

84. See District of Columbia Legal Aid Act $\S 2$, D.C. CoDE $\S 2-2201$ (1967).

85. See Criminal Justice Act of 1964, § 2, 18 U.S.C. $\S 3006 A$ (1964).

86. See id.; District of Columbia Legal Aid Act $\S 8$, D.C. Code $\S 2207$ (1967). 
provided for expert witnesses in those cases where an analysis of ballistics, narcotics, or blood tests may be crucial. The defendant should not be forced to rely solely upon the opinions of government experts. ${ }^{87}$

The third major problem commonly faced by defense counsel is the unwillingness of prosecution witnesses to discuss the case with defense counsel before trial, particularly in narcotics cases. In the absence of judicially supervised deposition practice, it may be appropriate that a potential witness should have the right to decline to talk with counsel, and, in unusual cases, a prosecutor should be able to obtain a protective order from the court if a witness is harassed..$^{83}$ But there can be no justification for government counsel explicitly or implicitly to silence a witness who would otherwise be willing to discuss the case with defense counsel. The cases are beginning to recognize the problem and to provide relief. ${ }^{89} \mathrm{H}$ opefully this trend will continue.

We submit that many of the real concerns of Ashford and Risinger can be alleviated by practical reforms including broadening the avenues of investigation in the manner suggested. The chances of improving the position of the innocent defendant through measures of this nature are much greater than through artificial suggestions designed primarily to restrict the use of presumptions, particularly since, after Turner, ${ }^{50}$ presumptions will play only a very diminished, although perhaps still not insignificant, role in the administration of criminal justice. Those who are genuinely concerned with the reform of criminal procedure would be better advised to focus their efforts on how the process actually works in practice than to concentrate their attention solely on the formal characteristics of the system. The symmetry of legal theory is important. How the law operates in practice is crucial.

87. See Jacobs v. United States, 350 F.2d 571 (4th Cir. 1965). Such funds are provided under the Criminal Justice Act of 1964, 18 U.S.C. $\S 3006$ A (1964).

88. Fed. R. Crim. P. 16(e).

89. E.g., Gregory v. United States, 369 F.2d 185 (D.C. Cir. 1966).

90. Turner v. United States, 396 U.S. 398 (1970). 